\title{
Halal Korean Food and Glocalization
}

\author{
N L Nadhifah ${ }^{1}$, S V Eka ${ }^{2}$, A Tusita ${ }^{3}$ \\ 1,2,3 Universitas Brawijaya, Indonesia \\ \{1lely_n@ub.ac.id, ${ }^{2}$ scarletina@ub.ac.id, ${ }^{3}$ arcci_tusita@ub.ac.id $\}$
}

\begin{abstract}
Korean food started to gain its fame in Indonesia after K-Pop wave is widely consumed in this country. Facing the fact that the majority of Indonesians are Muslim, people started to modify the ingredients of Korean food to reach the halal standard, which then promoted through many kinds of media. This study aims to analyze how the products of halal Korean food represented on online media. This kind of food is discussed in the context of its relationship with the representation of the customers' identity as Moslem. Drawing on data collected from posts about Korean halal food on Instagram and blog archives, as most sources are found in them. The data taken then are analyzed in order to understand the process of the hybridity products fulfill its progressive potential in a local context --in this case, halal context--. The findings show that Indonesians, with the majority of Moslems, are not only consuming Korean food and be part of the domination of the Korean wave but on the other hand, they also articulate their ideology of being cosmopolitan Moslems.
\end{abstract}

Keywords: Glocalization, Halal food, Korean food, Hybridity, Identity

\section{INTRODUCTION}

Food, people, and culture are things that difficult to separate. As human connects with each other, their ideas are produced in many forms: utterances, practices, gestures, and products. It is a biological nature of human to eat and share their ideas through food, which subsequently becomes a medium to show a certain group or culture. In a celebration of independence day, the national signature food is served and enjoyed together to show nationhood. This sense of identity is shown through food as the medium, and at the same time, food becomes one way to confirm and strengthen the identity. $\mathrm{Xu}$ [1] states that the relation between food, culture, and identity are closely related. Not only one field resulted in this notion, but many have the same results: foodway is the way of culture to express itself.

In the development of information technology and social media nowadays, the image of a nation can be shown and represented by food. Hallyu has come to the 4th wave, and through social media, Korea has a robust impact globally. America, Vietnam, and Middle East countries are the example of countries affected by Hallyu 4.0 [2][3][4]. Located in one regional Asia, together with Korea, Indonesia also severely impacted by Hallyu as demonstrated by so many fan groups around the nation [5][6][7].

Korea in Indonesia is exposed through popular TV programs such as Running Man, as well as through Instagram. Working globally, Instagram is considerably liked by Indonesian fans to keep updated with current information about Korea. In Instagram, Korea is represented 
as a nation with delicious food. As an example, hashtag \#koreanfood in Instagram is dominated by people eating an abundant portion of a dish, to justify that Korean food is delicious so that a person can finish the extra portion in a single meal.

The hashtag does not only contain images from Korea but also from Indonesia; indicating that there are also places providing Korean food in Indonesia. The development of Korean fandom in Indonesia has multiplied in one decade from 2008 to 2018[8]. Jeong [9] states that the Hallyu phenomenon in Indonesia is found not only in media cultural products (TV dramas, K-pop music videos, variety shows) but also in broader lifestyle products (foods, cosmetics, tourism). Food is the main products consumed by Indonesian fans and has triggered the proliferation of Korean Restaurant in Indonesia.

As the biggest Moslem country in Asia, Indonesia has a strong belief in Islam's way of life. The majority of Indonesians, the Moslems, will only consume halal food even though they are the most fanatic Korean fan group member. Indonesians adopt Korean culture while at the same time fulfill the Islamic way of life through creating Halal Korean food. That is the reason why this study aims to analyze how the products of halal Korean food represented on online media, in the context of its relationship with the representation of the customers' identity as Moslem. Moreover, this research also tries to examine the form of hybridity of the Korean food in order to not only fulfilling the halal standard but also to suit Indonesian taste since actually not many Indonesians like the taste of original Korean dish. Drawing on data collected from the posts about Korean halal food from Restaurant's posts on Instagram and blog archives, this study analyses Korean halal restaurants and their food.

\subsection{Research Method}

Since qualitative research method is quite a well-known method applied for social sciences research, so this research also applies qualitative research as its method. The data analyzed in this research are taken from both Instagram accounts of Halal Korean Restaurants -which are Kirin, Mujigae, and Lotteria-- and blog archives by the customers. From those Instagram accounts, the data are not only about the posts upload by the account owners, but also from the comments given by the customers themselves.

\subsection{Result and Discussion}

\subsubsection{The Strive to Provide Halal Korean Food}

As the influence of Korean dramas and Korean pop has been unprecedented, the demand for Korean food in the Islamic market such as Indonesia has increased due to the Korean wave including K-Pop. Halal food stems from religious practice for Muslim, and since Indonesia has a big Muslim population, halal is considered as an important notion and halal food itself is easily accessible. However, the term halal is a bit difficult to be implemented in Korean food because its several basic ingredients are made of non-halal materials, such as alcohol. 

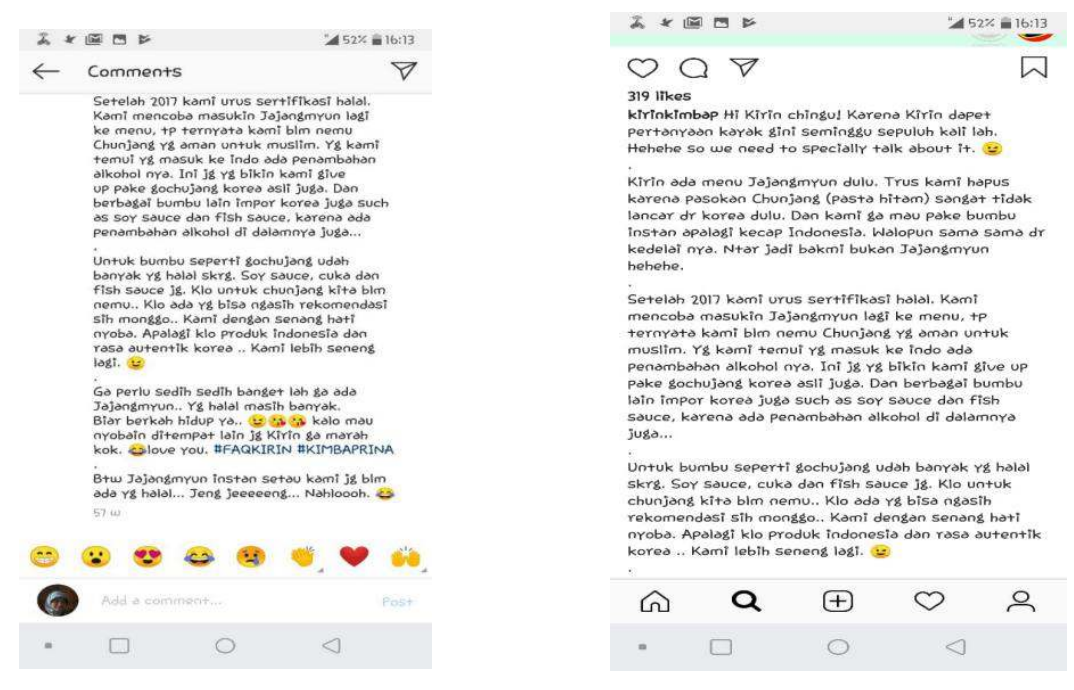

Figures 1 and 2. Basic ingredients in Korean Food.

Kirin or Kimbab Rina is one of several famous Korean restaurants in Malang, East Java. From the explanation in figures 1 and 2 above, it can be concluded that the restaurant struggles in finding halal main ingredients, most importantly chunjang or black paste- the main ingredient for Jajangmyun. In particular, Muslims have a high proportion of food items which are considered as taboo, and therefore to be a pious Muslims are important to consume only halal food as part of the religious practices [10]. Halal food in Islam means "permitted food" that Muslims should practice in significant ways, and food produced according to the Qur'anic religious law. Therefore, Kirrin has to temporarily erase Jajangmyun from the menu because the main ingredient contains alcohol which is "not save" to be consumed by Muslims. Another interesting point from the above explanation is that the owner insists to not replace chunjang with another ingredients like Indonesian soy sauce or instant seasoning, because chunjang is what makes Jajangmyun as Jajangmyun. Thus, the authenticity of Korean taste is also considered important.

In modern and globalized industry, some Muslim requirements have been met to be setting a new standard of production, preparation, handling, storage, and certificate [11]. The halal certification system which means reviewing the halal integrity and verifying compliance with the halal standard has made a great contribution to the systemic institutionalized of halal food. Therefore, it is important for Korean Food restaurants to get Halal certificate to ensure the consumers about the halal brand of their products. 


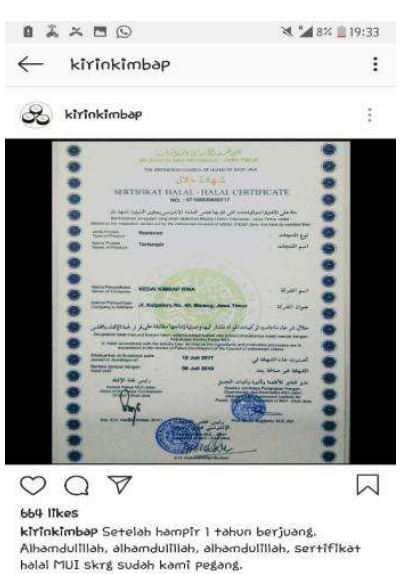

$\Omega$

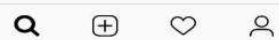

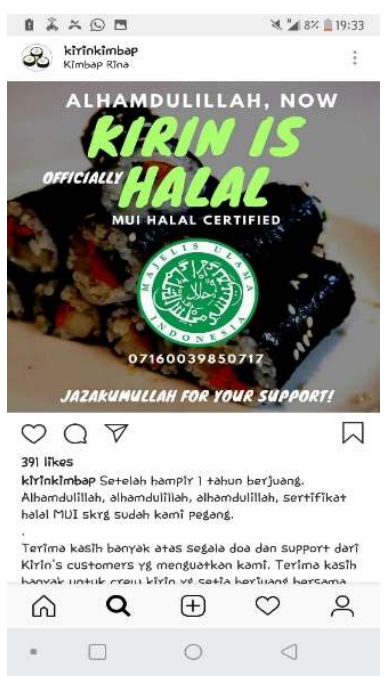

Figures 3 and 4. Kirrin's Halal Certificate from MUI.

Figures 3 and 4 depict the announcement of Halal certificate of Kirin issued by MUI (Majelis Ulama Indonesia). Having a halal certificate does not only serve as a marketing strategy of the restaurant but also is considered as an accomplishment. Since not many Korean restaurants are able to provide halal certificate from the government's institution, it is then deliberately highlighted as distinction, especially in Indonesia. It is proven by the two postings of Instagram above; the picture on the left shows the photo of an original halal certificate, while the picture on the right confirms that the restaurant is halal certified by putting the logo of MUI and the certificate number.

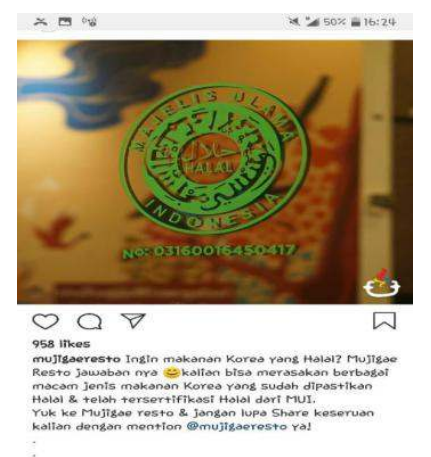

요 $\quad$ 우

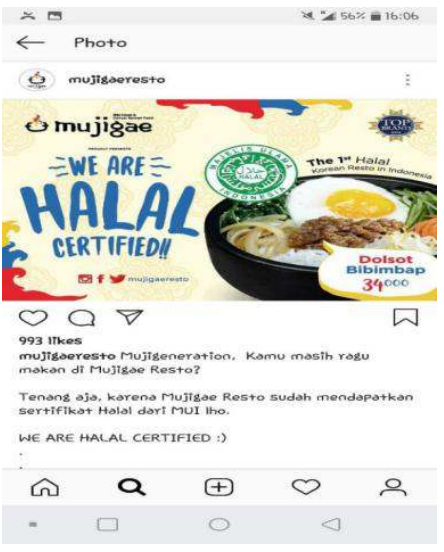

Figures 4 and 5. Mujigae is halal certified restaurant.

Not only Kirrin, Mujigae which is located in West Java also claims to be a Korean restaurant which has halal certificate from MUI. Similar with Kirin, Mujigae also posts the picture of MUI logo along with its certificate number as seen on the left picture above. While 
on the right picture, the halal certificate becomes a tool to get rid of consumers' doubts on the "safety" of Mujigae's products. It is true that providing halal brand can enhance the demand in the industry because consumers would then have confidence in a brand when they recognize it as admirable and pleasant.

\subsubsection{What Muslim Consumers Want From Korean Food - Halal, Affordable, and Familiar}

Not only the seller, but Indonesian Muslim customers also play important role in shaping a new discourse about desirable Korean Food in Indonesia. It can be seen from their active role in new media such as Instagram and blog. According to these customers, there are at least three main aspects that should be incorporated from Korean Food in Indonesia: Halal, familiar taste and affordability.

Religion has played an important role in consumption among people in different faiths, including Islam. It is interesting to study the relationship between religion and consumer behavior because consumers communicate their religious identities to others and express the intensity of their beliefs through consumption choices. For Muslim consumers in particular, buying food is more than purchasing, they also have to ensure that the food they are about to buy meet the need of devout Muslims. Thus, halal plays some roles in Muslim life - part of belief, essential daily living, ethical system, and emotional peace. It is clearly seen from figures 6 and 7 below.
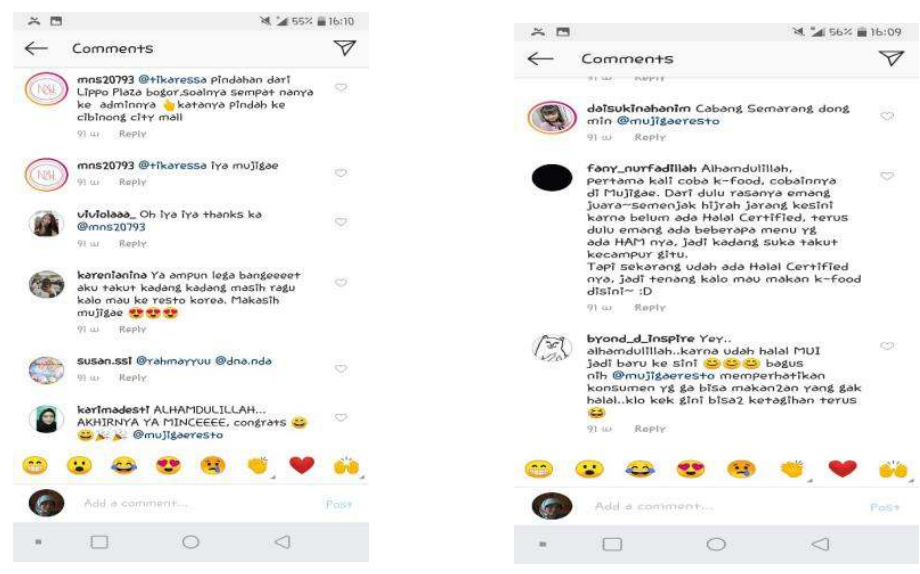

Figures 6 and 7. Halal certificate brings emotional peace to consumers.

Many Muslim customers express their relieve toward "good news" of their favorite Korean Restaurant, in this case, Mujigae gets the halal certificate from government's institution. Some other explain their previous concern about the "unclear" ingredients and the way the food cooked. Although the taste of the food is delicious, they seemed reluctant to consume the food without a halal certificate. One customer, byond_d_inspire, on the right picture even claims that he deliberately buys the food from Mujigae after it is halal certified. These pieces of evidence strengthen the claim that building a trustworthy Halal restaurant enables the business to appealthe consumers emotionally. Eventually, the trust from customers 
enhance their purchase intention, and it affects consumers' repetitive purchase behavior as well [12].
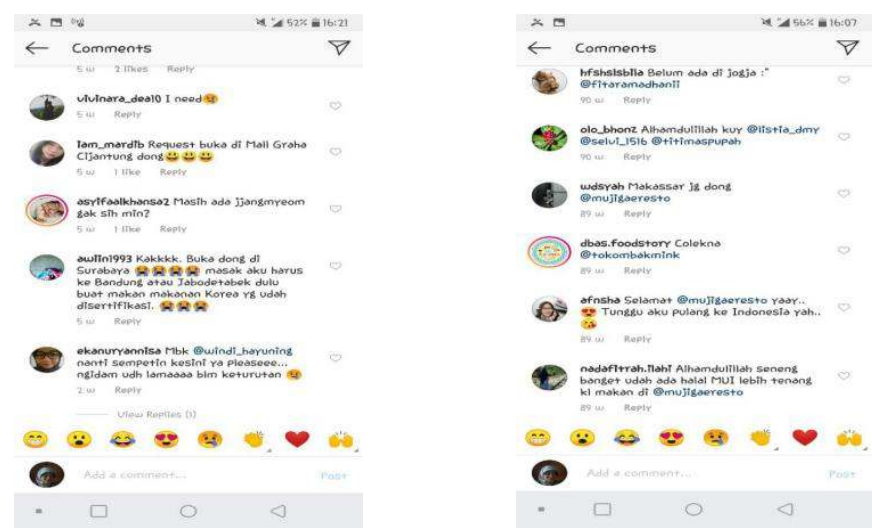

Figures 8 and 9. Customers' requests for more halal Korean restaurants

Further, the growth of halal-certified Korean Restaurants boosts consumers' interest in tasting and consuming halal Korean food. Limited Korean restaurants with halal certificate make many Korean food lovers voice unique requests for halal-certified Korean restaurants to open branches in their cities which can be seen from figures 8 and 9 above. Therefore, claiming the halal certificate can serve as a marketing strategy to expand the business and appeal to wider customers in Indonesia.

The second aspect that is considered appealing by Indonesian customers is that although Korean food needs to preserve its authenticity, it also must suitable for Indonesian taste. This aspect is depicted in figures $10,11,12$ and 13 below
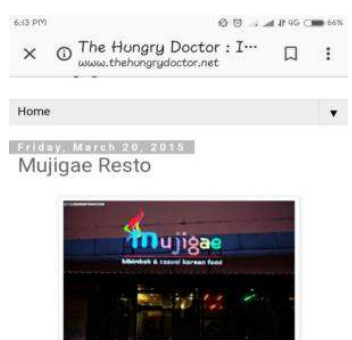

Hello readers!

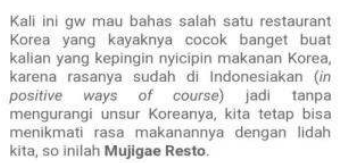

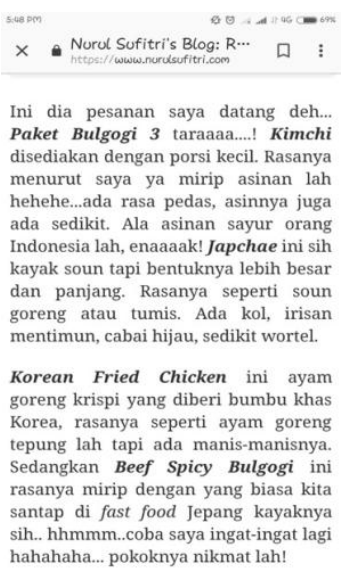

sih.. hhmmm..coba saya ingat-ingat lagi

Figures 10 and 11. Mujigae serves Korean food with Indonesian taste.

The left picture which is taken from thehungrydoctor [13] blog claims that makes Mujigae worth visiting is that the restaurant serves Korean food with Indonesian tastes (in a positive way). The addition "positive way" reflects that Indonesian touch in the food does not reduce its quality and excellence. Instead, it becomes the reason people should try its food 
since many people will be able enjoy the foods' taste. Lotteria, a Korean fast food franchise also highlighted for being able to embrace Indonesian taste through its food. Moreover, in the picture 13 on the below right, which is taken from yukk.co.id blog [14], is explained that Lotteria also uses Indonesian ingredients and seasoning to capture the market.
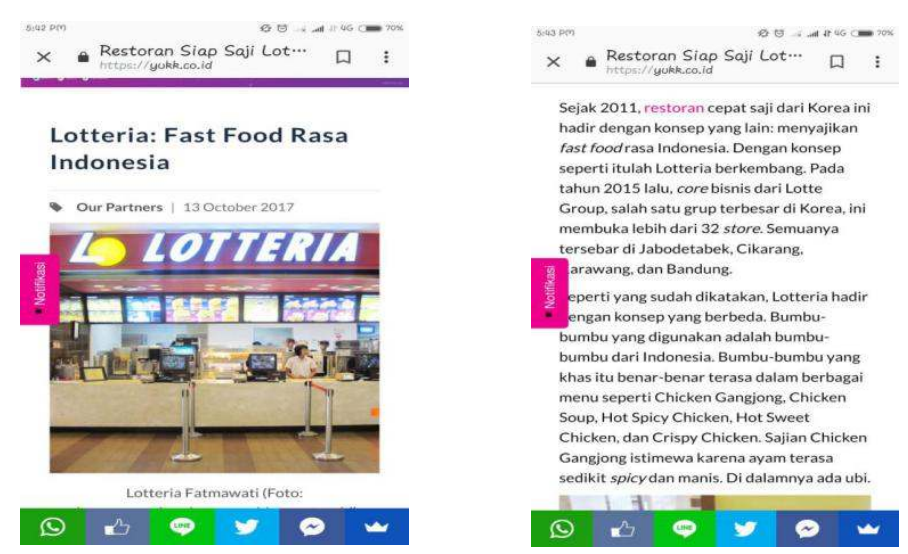

Figures 12 and 13. Lotteria: Korean fast food with Indonesian tastes and seasoning.

The last aspect that is considered important in consuming Korean food is the affordable price of the food. The majority of Korean food customers in Indonesia are youngsters who are also fans of Korean drama and K-Pop or those who are exposed to Korean pop culture. Many of Korean food lovers are students, and youngsters who do not think consuming Korean food equals having fine dining in luxurious restaurants. Instead, they consume Korean food while getting together with friends or family.
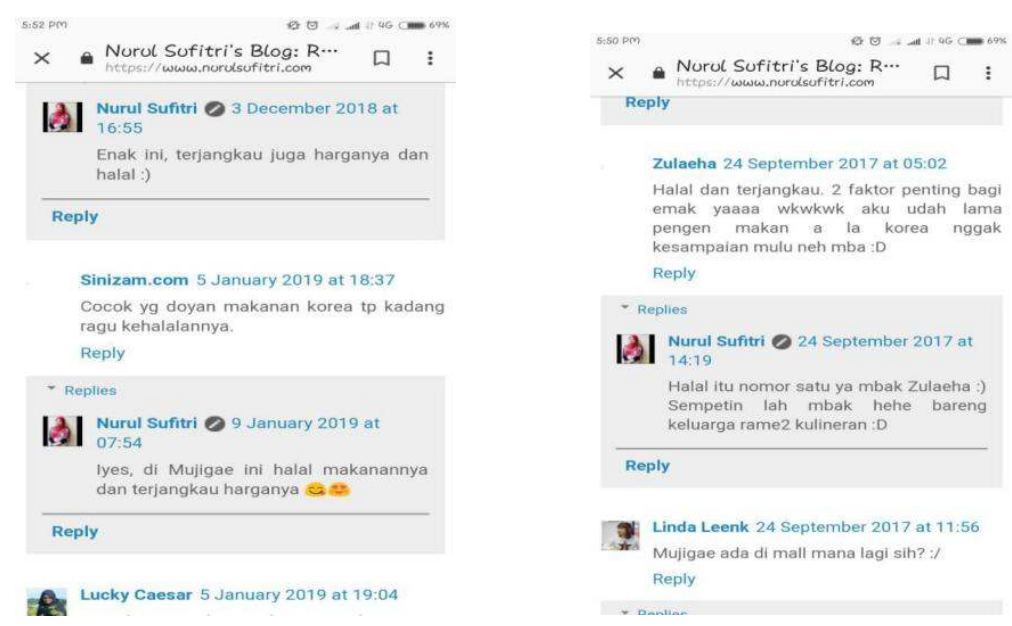

Figures 14 and 15. Korean foods need to be affordable.

Two figures above are taken from Nurul Sufitri's - a young Mom's - blog [15]. Many comments assert the importance of affordable Korean food since in Indonesia; married women 
are expected to be 'smart' about family budgeting. Consuming affordable Korean food is their way to celebrate their love in Korean pop culture and to be 'smart' buyer at the same time.

\subsubsection{Hybridity as the Matter of Halal Requirement and Taste}

For fulfilling the requirements for halal certificate food, those Korean restaurants are obliged to totally use halal ingredients, which means that they need to adjust and modify the spices and ingredients normally used for Korean dish. Nevertheless, there is more than just coping with halal requirement behind this hybridity phenomenon. A Korean restaurant owner stated that she needs to alter the ingredients so that those Korean dishes will be quite familiar for Indonesians. The hybridity of Korean food sold in Indonesia here is seen as a form of the negotiation of cultural differences and the reflection of relations among Muslim Indonesian customers and Korean food as part of Korean culture. Previous research on Indonesian customers' attitude toward foreign food shows that Indonesian customers love to consume certain type of food to represent their identity, but mostly they are not accustomed to the original taste. This means that they still prefer the one with the touch of local taste [16].
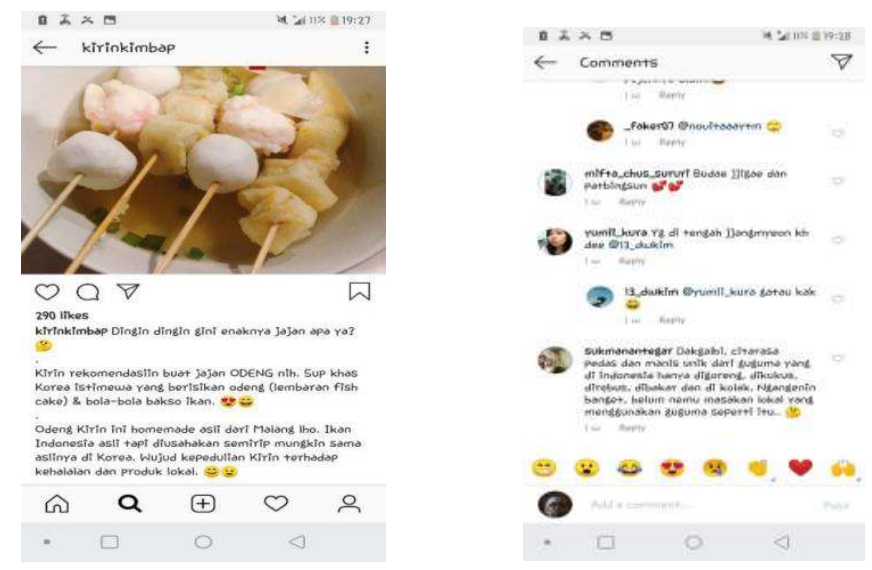

Figures 16 and 17. How Korean dishes also having local ingredients.

Figure 16 is taken from Kirin's Instagram page, where the owners stated that she cares about both local product and the authenticity of the taste of Korean dishes that she sells. While the comments in figure 17 is also taken from Kirin's Instagram page, where the customers expressed how she feels amazed of the way the local product is prepared in foreign way. 

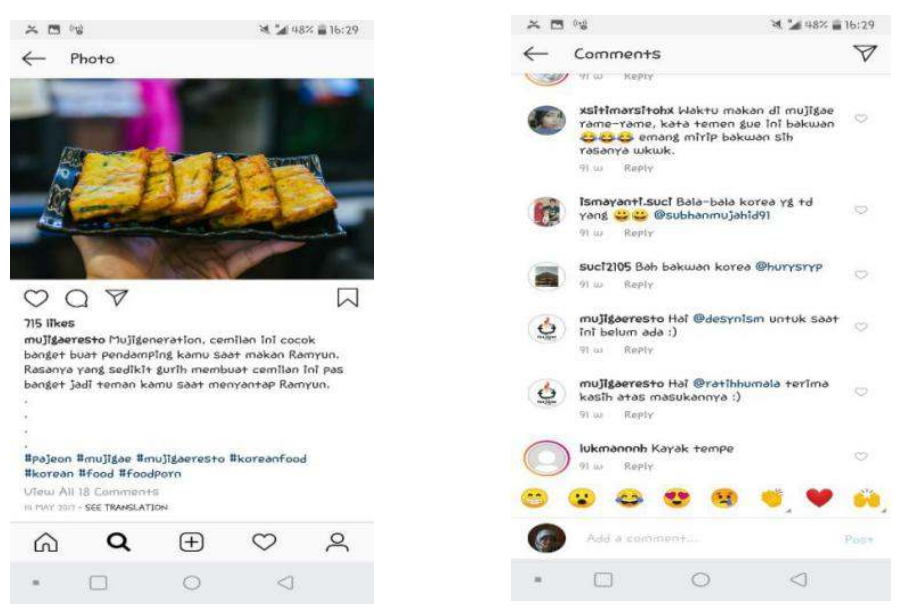

Figures 18 and 19. The way customers compared Korean dishes with Indonesian local cuisine.

When Mujigae posted one of its dishes called pajeon in their Instagram page (figure 18), many responses were given by the customers, as seen in figure 19, on how it looks like tempe --a local food from Indonesia-- and tastes similarly like one of Indonesian traditional food, bakwan. Pajeon is a green onion pancakes from Korea and is served with more local form and taste to meet the customers' need on something familiar with their everyday diet. This way, while fulfilling their need in expressing their identity as fans of parts of Korean culture, customers still face something acquainted with their own local culture.

Another form of hybridity is practiced by Lotteria, a Korean food restaurant chain that is quite famous in Indonesia. As stated by Park and Lee [17] that even in South Korea, the development of halal food is increasing rapidly due to the fact that Muslim population continues to grow steadily and globally. According to Park and Lee [17], the development of standardization and certification system for halal food has led multinational food companies in South Korea to occupy the halal market. Applied in this case, Lotteria also already gained its halal certificate as well. As a fast food restaurant, Lotteria serves the typical fast food dishes, where crispy fried chicken and burger can be found on the menu. A different way of glocalization is offered to the customers. By taking fast food restaurant chain as its concept where Lotteria could spread its branches around the world, Lotteria has to adapt its Korean menu into the more global ones, which are easier to be accepted by global consumers. 


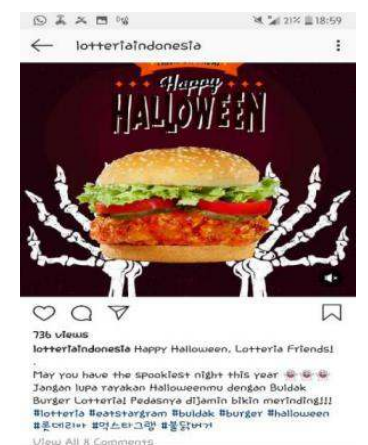

凡
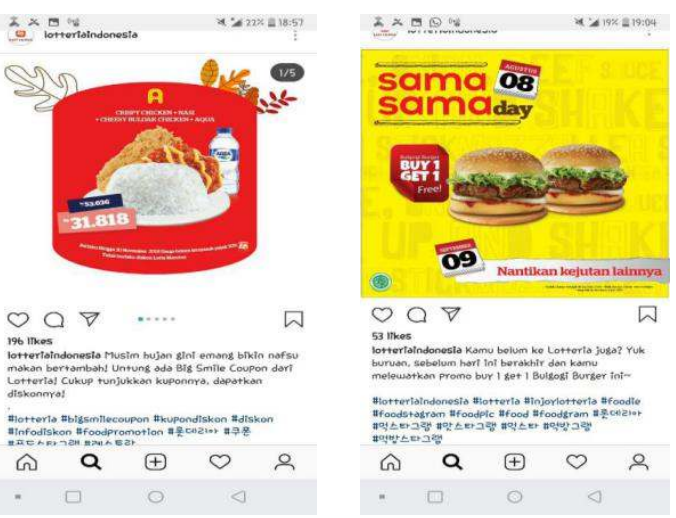

Figures 20, 21, and 22. Glocalization in Lotteria

Advertised with Halloween theme which was started in Europe then adopted by other parts of the world, Lotteria introduced its buldak burger, a hybrid between Korean local cuisine, buldak --which is spiced and barbecued chicken--, and burger as a global food as seen in figure 20. Another dish with the same style is bulgogi burger, which can be seen in figure 22 . Both menus are offered adn served in order not only to introduce Korean cuisine to the world but also to fulfill the international customers' demand on familiar taste.

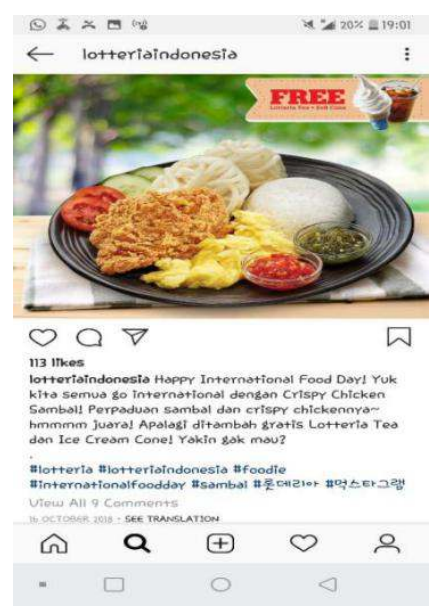

Figure 23. When Lotteria decided to put Indonesian local cuisine into display.

When Lotteria decided to put local Indonesian cuisine into the display, Lotteria took a step forward when it introduced another menu with a taste of local Indonesian food in it. Applying the hashtag \#internationalfoodday, Lotteria adds two famous Indonesian local food, sambal (chili paste) and kerupuk (chips), into its global menu --crispy chicken and scrambled egg-- as seen in figure 23. Lotteria's way of using \#internationalfoodday is not about putting all the global dishes that people mostly know in the menu; instead, Lotteria mix three aspects into this form of hybridity: crispy chicken and scrambled egg as parts of the global, rice which represents Asia, and both sambal and kerupuk as the local cuisine from Indonesia. 


\section{CONCLUSIONS}

As discussed before, the hybridity of Korean food sold in Indonesia on Instagram is seen as a form of the negotiation of cultural differences and the reflection of relations between both Muslim Indonesian customers and Korean food as part of Korean culture. As Muslims are strictly required to consume only halal food, their way of representing their identity as fans of Korean culture --where consuming Korean food has become one of the main aspects-- is facing some troubles since Korean food is known as having some non-halal ingredients. Aside from that, the customers also demand the familiarity in taste for the Korean food that they consume. Hybridity in Korean food sold in Indonesia is formed as an entanglement of three different aspects; (1) the obligation of fulfilling the requirements of halal food, (2) the Korean food ingredients which mostly contain non-halal substances, and (3) the customers who require familiar taste on the dish that they want to consume. This hybridity enables Indonesian Muslim customers to construct their identity as both Muslim and Korean culture fans.

\section{REFERENCES}

[1] $\mathrm{Xu}$, Wenying. 2008. Eating Identities: reading food in Asian American literature. Honolulu: University of Hawai'i Press

[2] Yook; Yuk; Kim. 2014. The Effects of Hallyu (Korean Wave) on the Ethnic Identity of Korean Transnationals in the US. Sian Communication Research 3(3): 5-12.

[3] Truong, Nguyen Xuan. 2018. The Impact of Hallyu 4.0 and Social Media on Korean Products Purchase Decision of Generation C in Vietnam. The Journal of Asian Finance, Economics and Business 5(3): 81-93. DOI: 10.13106/jafeb.2018.vol5.no3.81.

[4] Elaskary, Mohamed. 2018. The Korean Wave in the Middle East: Past and Present. $J$. Open Innov. Technol. Mark. Complex. 2018, 4(4), 51. DOI: 10.3390/joitmc4040051

[5] Wuryanta, E. (2012). Di antara Pusaran Gelombang Korea (Menyimak Fenomena K-Pop di Indonesia). ULTIMA Comm, 4(2), 79-94. DOI: 10.31937/ultimacomm.v4i2.209

[6] Fitriyani, A. (2016). Fenomena Fangirl K-Pop di Indonesia (Universitas Airlangga). Diakses dari http://anita-fitriyani-fisip15.web.unair.ac.id/artikel_detail-161789psikologi\%20sosial-Fenomena\%20Fangirl\%20KPop\%20di\%20Indonesia.html.

[7] Akmaliah, Wahyudi. 2013. Memahami Fenomena Hallyu (Gelombang Korea). Jurnal Masyarakat dan Budaya 15(1): 201-212

[8] Muchtar, Joy. 2018. Hallyu: Surfin' the Korean Wave in Indonesia. Jakarta Globe. jakartaglobe.id/culture/riding-the-wave-of-south-korean-pop-culture-in-indonesia.

[9] JEONG, JAE-SEON. 2017.When Indonesians Routinely Consume Korean Pop Culture: Revisiting Jakartan Fans of the Korean Drama Dae Jang Geum . International Journal of Communication 11(2017): 2288-2307

[10] Cho, Hee-Sun, et al. 2008. Muslim Communities in Korean Society: Focusing on the influx, adaptation and social network of Muslim Immigrants in Korea. Journal of Institute of the Middle East Study, 27(2), 81-124

[11] Fischer, Johan . 2015. Muslim consumption and anti-consumption in Malaysia. Tidsskrift for Islamforskning, 9(2), 68-87.

[12] Borzooei, M. and Asgari, M. 2013. The Halal Brand Personality and It's Effect on purchase Intention. Interdisiplinary Journal of Contemporary Research Business. Vol. 5, No. 3. July 2013.

[13] Tanu, V. D. 2019. Mujigae Resto. Retrieved February 13, 2019, from http://www.thehungrydoctor.net/2015/03/mujigae-resto.html 
[14] Lotteria: Fast Food Rasa Indonesia. (2017, October 17). Retrieved February 13, 2019, from https://yukk.co.id/blog/lotteria-fast-food-rasa-indonesia.html

[15] Sufitri, N. 2019. Review Mujigae, Restoran Makanan Korea Halal di Margo City Mall. Retrieved February 13, 2019, from https://www.nurulsufitri.com/2017/09/reviewmujigae-restoran-makanan-korea.html

[16] Nadhifah, Nurul Laili, Tusita, Arcci, Herminingrum, Sri. (2016). 'A Study of Food and Cultural Identity Representation of Young Customers', in ICOAH 2016: 3rd International Conference on Arts and Humanities, TIIKM, INdonesia, 110-114.

[17] Park, JH. 2017. Globalization of Halal Food:sep:A Study on Its Diffusion 'into' and Export 'from' South Korea. Journal of the Law 26(2): 131-142. DOI: http://dx.doi.org/10.21189/JKUGS.20.3.10 